\title{
真空持続ドレーンによる術後出血量の測定
}

山口県立中央病院整形外科

$\begin{array}{llrlll}\text { 菅 } & \text { 井 } & \text { 治・舌 } & \text { 間 } & \text { 憲 } & \text { 士 } \\ \text { 马 } & \text { 削 } & \text { 大四郎・伊 } & \text { 藤 } & \text { 孝 } & \text { 徳 } \\ \text { 久 } & \text { 保 } & \text { 央 } & & & \end{array}$

\section{Post Operative Bleeding}

By

\author{
O. Sugai, K. Shitama, D. Yuge, \\ T. Itoh, \& M. Kubo \\ Division of Orthopedic Surgery, Yamaguchi Prefectural \\ Central Hospital, Hofu, Yamaguchi
}

(1) By the use of drain with a vaccum bottle (Redon's drain), quantity of post-operative bleeding in orthopedic operations of 323 patients (352 operations) were observed.

(2) In total average the post operative bleeding indicated 23.1 per cent of blood loss during surgery.

Especially the quantity of post-operative bleeding in hip joint and lumbar spine operation more increased.

(3) The quantity of post operative bleeding in 21 reoperative cases increased 59 per cent more than that in first operation.

(4) This method observation was of use easily to determine quantity of blood and solution transfusion in post operation.

真空吸引瓶を使用した drainage aspiratif de Redon (Redon のドレーン) を手術時, 創内に留置 し，術後の血腫除去の目的で使用しはじめて 3 年を経 過した．乙の術後吸引血液量の合計を術後出血量と考 え，323 症例，352 回の各手術の術後出血量を測定し たので報告する.

\section{原理と使用法（図1)}

詳細は “整形外科” 20 巻 9 号に掲載したので省略 する．要点は $500 \mathrm{cc}$ の硬質ガラス瓶につけた水パッ キンを内蔵するゴム栓である（図１の１），注射器で 真空調節バルブのガラス管より水を注入し，水パッキ ン内に水をためて吸引口よりサクションポンプで瓶内 を吸引する．瓶内が陰压になるとともにガラス管の水 位が下がり，水パッキン内腔が大きくなり, ゴム栓と 瓶の口との間隙が消失し瓶内の真空が保てる．これで 真空吸引瓶が出来上る. 最高 $650 \mathrm{mmHg}$ の真空度が
あり，吸引量調節 ストッパーでその吸引力を調節す る.

于術部では，一応所期の手術が終ったら（たとえば 骨折の場合，骨接合が終ったら)，その部にガス滅菌 された埋没カテーテルの多孔の 部分を入れ, 反対側 は誘導穿刺針をつけて創縁より $2.5 \mathrm{~cm}$ ぐらいはなれ た部位の皮膚を通し創外に出す．抜けない上うに皮膚 とカテーテルを絹系で縫合固定し，連絡チューブを介 して真空瓶之接続する. 創閉鎤後, 吸引量調節ストッ パーをあけ吸引を開始する.

持続吸引中常に吸引の状態を監視し，むし真空調節 バルブのガラス管に水柱があがっていたら，てのビン 内はすでに真空ではないので，（カ）の連絡チューブ を抜いてサクションポンプでビン内を再び真空にして から吸引を持続する．大体，術後 48〜 72 時間でドレ ーンを抜去し，その吸引量の合計を記録し術後出血量 とした. 


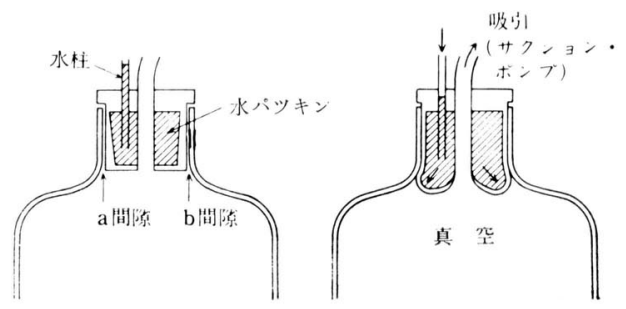

a. 真空でないとき。

b. 真空時.

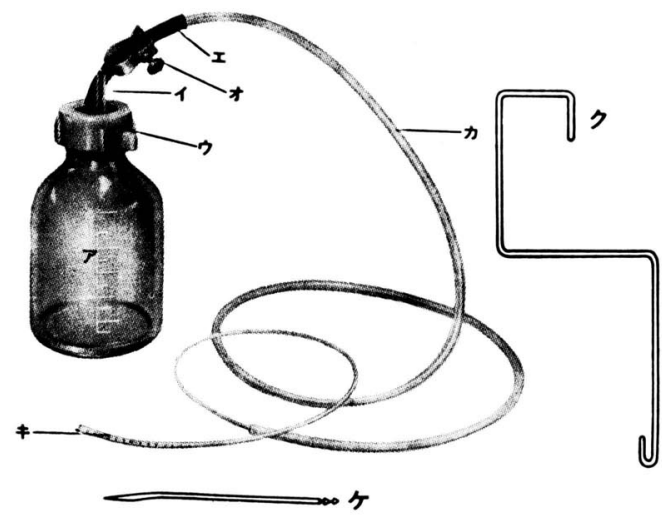

ア：吸引ビン $500 \frac{m}{m} \mathrm{~L}=760 \frac{m}{m} \mathrm{Hg}$ の真空にたえる 硬質ガラス製.

イ, ウ：真空度調整バルブ＝（イ）のガラス管と （ウ）の内部ゴム栓がバルブを構成する。この ガラス管にあらかじめ水を入れ真空を開始す ると管の水はゴム栓内に徐々に吸い込まれる ので水位によって真空度が予見できる。

エ：吸引接続ゴム管二このゴム管に(カ)の連絡チ ューブを差込むだけでよく，また(オ)の吸引 量の調節ストッパーむとりつけられている.

才：吸引量調節ストッパー二ネジを右にまわすと （エ）の接続ゴム管の内腔を圧迫して吸引量を 調節する. 左に回転すれば吸引瓶内压一杯に 吸引する。

力：連絡チューブ二特殊ビニールの耐圧チューブ で外径 $6.5 \mathrm{~m}$.

キ：埋没カテーテル =外径 $3 \mathrm{~m} / \mathrm{m}$ の 特殊ビニール 製多孔部分の長さは $90,65,35$ m で全長 490 m

ク：吊下げ鈎 =ベットに吊りさげるための鈎で (ウ)のロ金に取りつける。

ケ：誘導穿刺針二埋没カテーテルの多孔側の反対 に差しこみ,この穿刺針で創内に誘導し, 力 テーテルを留置させる.

図 1 真空ドレーンの構成と機能

\section{対象}

1967 年 6 月より 1971 年 3 月までの 四肢骨折の骨接 合術 139 例（151 回），変形性股関節症に対する大腿 骨骨切り術 23 例 (30回), 人工骨頭置換術や cap arthroplastie など 5 例（10回），肢切断 11 例，頸椎 前方固定術 7 例, 腰椎後方固定術 4 例, 腰椎椎間板一 ル二ア摘出術 38 例（41 回），骨䯙炎の搔爬や骨移植 術など 16 例（17 回），主に下腿開放骨折や挫創など の débridement 29 例, 膝関節内やその周囲の于術 16 例（17 回)，拔釷その他 35 例など計 323 症例， 352 回の各手術例を対象とした．年令は 2 才より 89 才ま でで平均 37 才である.

\section{結＼cjkstart果（表1・2）}

術後吸引量を術後出血量として各手術々式別にま之 めてみると, 骨折の骨接合術のうち大腿頸部骨折で は， $\mathrm{Y}$ 式螺子使用例で平均 $111 \mathrm{cc}$ であるが， McLaughlin 釗やJuwett 釷などの使用例では $259 \mathrm{cc}$ と2 倍以上の出血量を記録している. これは手術侵襲 のみでなく，粉砕気味の骨折など程度の強い骨折に Juwett 釷などを使用しているととにもよると思われ る.

大腿骨幹骨折の骨接合術では clover 釘と plate 固 定で平均 $158 \mathrm{cc}, 178 \mathrm{cc}$ と大きな差はないが，偽関 節手術として行った decortication 術後では平均 234 cc と増量している. 下腿骨接合術では clover 釗に 上る術後が $175 \mathrm{cc}$ と大腿骨幹部骨接合とほぼ同量の 後出血をみるが，plate 固定では少い，上腕骨々接合 では $100 \mathrm{cc}$ 以下であった.

変形性股関節症に 対する大腿骨々切り術では平均 $131 \mathrm{cc}$ と比較的少いが, 人工骨頭置換術や cap arthroplastie など股関節内をあつかう手術では 382 cc と最も多い後出血量を記録した. 次いで腰椎後方 固定術が $338 \mathrm{cc}$ と多く, 頸椎前方固定術では $100 \mathrm{cc}$ 以下となっている.

腰椎々間板へルニア摘出術での Love 法は平均 101 cc 上少いが, 椎弓切除を行った摘出術では $219 \mathrm{cc}$ 上 Love 法の 2 倍以上の出血をみている, 肢切断, 骨䯣 炎手術などは思ったより少量であった.

同一手術々式で再手術を行った 21 症例の後出血量 について初回の後出血量と比較してみると, ほとんど の例に増量が著明で, 全体の平均で $59 \%$ の術後出血 量の増加を認めた。

次いで, 術中出血量に対する術後出血量の割合を各 手術々式により比較してみると（表 2 ），骨接合術で は, 大腿で術中出血量の 20〜 24\%程度, 下腿で 24〜 $30 \%$ 程度の量の術後出血量をみている. 肢切断では 
表 1 手術後出血量 (吸引量)

\begin{tabular}{|c|c|c|c|c|c|}
\hline 手 & 術名 & \multirow{2}{*}{$\begin{array}{c}\begin{array}{c}\text { Redon } \\
\text { 使用数 }\end{array} \\
32 \\
12\end{array}$} & \multirow{2}{*}{$\begin{array}{c}\text { 最 } \\
(c c)^{\text {高 }} \\
290 \\
630\end{array}$} & \multirow{2}{*}{$\begin{array}{c}\text { (cc) } \\
20 \\
50 \\
50\end{array}$} & \multirow{2}{*}{$\begin{array}{l}\text { 平 }(\text { cc) } \\
111 \\
259\end{array}$} \\
\hline 大腿頸部骨折 & $\begin{array}{llll}\mathrm{Y} & \text { 式 } & \text { 螺 } & \text { 子 } \\
\text { 翼 } & \text { 釷 } & \end{array}$ & & & & \\
\hline 大腿骨幹部骨折 & 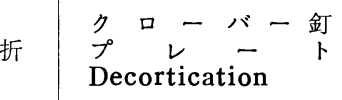 & $\begin{array}{r}19 \\
17 \\
5\end{array}$ & $\begin{array}{l}475 \\
510 \\
400\end{array}$ & $\begin{array}{r}50 \\
5 \\
85\end{array}$ & $\begin{array}{l}158 \\
178 \\
234\end{array}$ \\
\hline 下＼cjkstart腿＼cjkstart骨 & 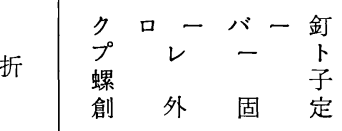 & $\begin{array}{r}12 \\
21 \\
13 \\
5\end{array}$ & $\begin{array}{l}505 \\
390 \\
170 \\
310\end{array}$ & $\begin{array}{r}20 \\
5 \\
10 \\
70\end{array}$ & $\begin{array}{r}175 \\
109 \\
72 \\
114\end{array}$ \\
\hline 上＼cjkstart腕＼cjkstart骨 & $\begin{array}{l}ク \\
\text { プ レー バー 釘 }\end{array}$ & $\begin{array}{l}6 \\
9\end{array}$ & $\begin{array}{l}200 \\
160\end{array}$ & $\begin{array}{l}10 \\
40\end{array}$ & $\begin{array}{l}79 \\
98\end{array}$ \\
\hline 抜 & 釘 & 9 & 180 & 5 & 81 \\
\hline 股 関 節 部 & $\begin{array}{l}\text { 大腿骨骨切り術 } \\
\text { 人工骨頭置換術など }\end{array}$ & $\begin{array}{l}30 \\
10\end{array}$ & $\begin{array}{l}435 \\
720\end{array}$ & $\begin{array}{r}5 \\
150\end{array}$ & $\begin{array}{l}131 \\
382\end{array}$ \\
\hline 肢切 & $\begin{array}{l}\text { 腕 } \\
\text { 腿 }\end{array}$ & $\begin{array}{l}6 \\
5\end{array}$ & $\begin{array}{l}100 \\
100\end{array}$ & $\begin{array}{l}5 \\
5\end{array}$ & $\begin{array}{l}38 \\
60\end{array}$ \\
\hline 脊 & $\begin{array}{l}\text { 頸椎前方目定術 } \\
\text { 腰椎方固定術 }\end{array}$ & $\begin{array}{l}7 \\
4\end{array}$ & $\begin{array}{l}110 \\
680\end{array}$ & $\begin{array}{r}15 \\
100\end{array}$ & $\begin{array}{r}86 \\
338\end{array}$ \\
\hline $\begin{array}{l}\text { 椎間板へル } \\
\text { 摘 出 術 }\end{array}$ & $\begin{array}{l}\text { Love 法 倠 } \\
\text { 号 切 }\end{array}$ & $\begin{array}{r}37 \\
4\end{array}$ & $\begin{array}{l}250 \\
250\end{array}$ & $\begin{array}{r}10 \\
185\end{array}$ & $\begin{array}{l}101 \\
219\end{array}$ \\
\hline 骨道 & 手 & 17 & 900 & 5 & 127 \\
\hline Dèbridement & （膝 部〜下 腿） & 29 & 300 & 5 & 89 \\
\hline 膝＼cjkstart関 & 節 ，部 & 17 & 430 & 2 & 79 \\
\hline そ & の & 26 & 520 & 5 & \\
\hline
\end{tabular}

あっとも少なく $7 \%$ 強で, 術中, 断端部を筋肉弁で被 い, 髄腔よりの出血を扣さえることや, 術後の圧迫包 帯法のためと思われる. 腰椎後方固定術やヘルニア摘 出術は, 術中出血量の $30 \%$ を越えている. Love 法は 術中出血量の少ない割に術後出血量が多いととを物語 っている.

全手術症例の平均は $23.1 \%$ となり, 整形外科手術 の術後出血量はほぼこの程度であると考えられる。

\section{考案}

整形外科領域での術中出血量の測定は大規模な調査 が行なわれ，その報告む多いが，術後出血量について は，その方法がむづかしいととから，ほとんど報告を みない，われわれはミズホ医科工業の協力を得て,

Redon の drain を作成し, 主に術後の 血腫除去の 目的に使用した，乙の術後吸引量は，ドレーンの埋没
の方法や吸引力の調節の 仕方により多少の増減があ り，正確な術後出血量ではないかむ知れないが，同一 条件下での術後出血量と考えて今回の検討を行ってみ た.

中野らは骨䯣に 侵警を加えた手術時出血の $50 \%$ 以 上が骨䯣出血であると述べている，われわれの術後出 血量測定でもとの傾向は強い，特に股関節，腰椎，長

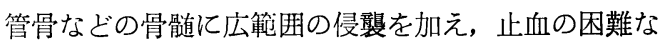
場合に術後出血が多い。また，再手術例では初回の術 後出血より $59 \%$ 増量している. 神経剝離術, 腱切 り術など軟部組織の手術後の出血量は, 手術時出血量 に比べきわめて少なかった。

\section{結酛}

(1) 真空持続ドレーン (Redon) を使用し 323 症 例, 352 回の各手術の術後出血量を測定した結果, 術 
表 2 手術中出血量に対する術後出血量の割合

\begin{tabular}{|c|c|c|}
\hline 手 & 術 & $\begin{array}{c}\text { 術後出血量 } \\
(\%)\end{array}$ \\
\hline 大腿頸部骨折 & 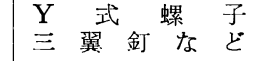 & $\begin{array}{l}19.6 \\
20.1\end{array}$ \\
\hline 大腿骨幹部骨折 & $\begin{array}{l}\text { クローバー釘 } \\
\text { プレー } \\
\text { Decortication }\end{array}$ & $\begin{array}{l}20.3 \\
24.2 \\
24.0\end{array}$ \\
\hline 下 腿 骨 折 & 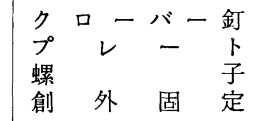 & $\begin{array}{l}29.6 \\
24.3 \\
24.4 \\
29.4\end{array}$ \\
\hline 上腕 骨 折 & $\begin{array}{l}\text { クローバー釘 } \\
\text { プレート及び螺子 }\end{array}$ & $\begin{array}{l}25.3 \\
20.3\end{array}$ \\
\hline 抜 & 釘 & 21.7 \\
\hline 大 奟退 骨頭 & 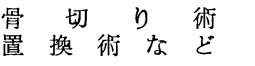 & $\begin{array}{l}17.6 \\
29.0\end{array}$ \\
\hline 切 断 & 上 & $\begin{array}{l}7.4 \\
7.1\end{array}$ \\
\hline $\begin{array}{lll}\text { 頸 } & \text { 椎 } & \text { 前 } \\
\text { 腰 } & \text { 椎 } & \text { 後 }\end{array}$ & $\begin{array}{llll}\text { 方 } & \text { 固 } & \text { 定 } & \text { 術 } \\
\text { 方 } & \text { 固 } & \text { 定 } & \text { 術 }\end{array}$ & $\begin{array}{l}19.7 \\
31.0\end{array}$ \\
\hline ヘルニア摘出術 & $\begin{array}{cc} & \text { Love 法 } \\
\text { 椎 } & \\
\text { 弓 切 除 }\end{array}$ & $\begin{array}{l}30.2 \\
39.5\end{array}$ \\
\hline $\begin{array}{ll}\text { 骨 } & \text { 髄 } \\
\text { 膝 } & \text { 関 } \\
\text { 節 }\end{array}$ & $\begin{array}{lll}\text { 炎 } & \text { 手 } & \text { 術 } \\
\text { 部 } & \text { 手 術 }\end{array}$ & $\begin{array}{l}26.9 \\
16.7\end{array}$ \\
\hline 平 & 均 & 23.1 \\
\hline
\end{tabular}

中出血量の平均 $23.1 \%$ の術後出血量があった. 特に, 股関節，腰椎の術後出血量が多かった。

(2) 再手術例（21症例）では初回于術の術後出血 量より $59 \%$ の増量があった.

(3) この術後出血量測定は, 創内の血腫を除去して 術後感染を予防するとともに, 術後の輸液, 輸血の算 定の目安となった。

\section{文献}

1）肾玉：日輸血学会誌， $5 ， 56 ， 1958$,

2） 鶴海：中部整災誌，1，197，1958.

3）中野：臨床外科, 12, 467, 1957.

4）肾玉：臨床整形外科全書， 1, 金原出版。

5）弓削：整形外科， 20, 1011，1969.

6) Lataste, J. : Presse Médicale, 74, 31, 1961.

質 問 中国労災整形 平 川 宽 各種于術の術後出血量の測定值を興味深く伺った. 䯣内釷法の場合，閉鎖性と開放性でどのような差があ ったか打教え頂きたい。

解 答 崖品整形外科 菅井 治

Clover 釷在使用した骨接合術で，閉鎖性に入れた あのの出血量が開放性のそれよりあ少かった. 閉鎖性 の場合, ドレーンは Clover 釬刺入部位に留置した。 